\title{
Training as an internal marketing tool within the franchise system
}

\author{
Carmen Domínguez-Falcón, Margarita Fernández-Monroy and \\ Inmaculada Galván-Sánchez \\ Instituto Universitario de Ciencias y Tecnologías Cibernéticas, \\ Universidad de Las Palmas de Gran Canaria, \\ Las Palmas de Gran Canaria, Spain, and \\ José Luis Ballesteros-Rodríguez
}

Instituto para el Desarrollo Tecnológico y la Innovación en Comunicaciones (IDe TIC), Universidad de Las Palmas de Gran Canaria, Las Palmas de Gran Canaria, Spain

Received 28 July 2020 Revised 18 November 2020 12 January 2021

Accepted 27 January 2021

\begin{abstract}
Purpose - The purpose of this paper is to analyse the important role of training (specifically, training relevance and training transfer) in enhancing franchisor-franchisee relationship satisfaction, and its influence upon customer performance (e.g., customer satisfaction, quality service), all driven by an internal marketing (IM) culture.

Design/methodology/approach - An empirical study consisting of a questionnaire was conducted on a final sample of 157 individuals who are members of the franchise system. Structural equation modelling (SEM) was used to test the research hypotheses.

Findings - The results reveal that IM culture has a direct influence on training relevance; likewise, training relevance provides a positive and significant effect on training transfer, which does directly affect franchisorfranchisee relationship satisfaction and at least also impacts indirectly on customer performance.

Practical implications - In order to ensure the success of the franchise system and customer satisfaction, all franchise parties should take a proactive role in the configuration of the training programmes. This proactive role should be conformed based on an IM culture developed properly by the franchise to strengthen a successful long-term relationship.

Originality/value - This paper provides an innovative approach to strengthen the franchisor-franchisee relationship through training based on the IM culture. This exploratory study integrates different theoretical frameworks that, to our knowledge, have not been linked, such as IM culture and franchise literature, considering the franchisee as an internal customer who has an influence on external customer satisfaction, with training and training transfer as essential key factors.
\end{abstract}

Keywords Internal marketing, Training relevance, Training transfer, Relationship satisfaction, Customer performance, Franchise

Paper type Research paper

\section{Introduction}

Franchising is "the wave of the future". This quote by Ioanna and Maria (2013, p. 629) confirms the great interest that the franchise has and will continue to have as a proven business format. The key to its success is based on the development of quality relationships between franchisor and franchisees, which is why the literature continues to emphasize the need for further study (e.g., Altinay et al., 2014a). In fact, there is a recent research trend that reinforces the idea that beyond the mere contractual exchange between the parties, the franchise has an important relational dimension (Fernández-Monroy and Melián-Alzola, 2005; King et al., 2013; Lee et al.,

The authors are grateful to the two anonymous referees for the critical reading of the manuscript and their valuable comments which have contributed substantially to improve the research paper.

The authors disclosed receipt of the following financial support for the research, authorship and/or publication of this article. This work was supported by the Programa de Ayudas a la Investigación de la ULPGC. Convocatoria 2018 [ULPGC2018-06].

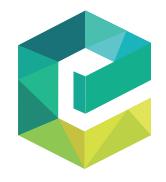

Journal of Service Theory and Practice (C) Emerald Publishing Limited DOI 10.1108/JSTP-07-2020-0173 
2015; Rosado-Serrano and Paul, 2018; Perrigot et al., 2019; Kim et al., 2020). Based on the above, the development of satisfactory relationships between franchisor and franchisee leads to better quality customer service and greater benefits (Bordonaba-Juste and Polo-Redondo, 2008; Davies et al., 2011; Nyadzayo et al., 2011; Lee et al., 2015; Ghantous and Das, 2018). In this regard, training has been fundamental in facing the complex and difficult environment in which franchisor-franchisee relationships are developed (Ioanna and Maria, 2013). Training has been broadly studied as a key aspect in franchise systems (Frazer et al., 2007; Ioanna and Maria, 2013; Altinay et al., 2014b; Altinay et al., 2014a; Perrigot et al., 2015). However, according to Choo and Bowley (2007), research has mainly focused on considering training only as one of the elements of the overall franchisee package.

To overcome this partial view, this study involves analysing training in terms of two key aspects indicated in the literature: (1) the degree to which training is perceived to be useful and relevant to the job, since it is designed to meet franchisee needs (training relevance), and (2) the degree to which training is finally transferred to the job itself (training transfer). The training provided could affect franchisor-franchisee relationship satisfaction (Harmon and Griffiths, 2008; Grace and Weaven, 2011), increasing cooperation (Gassenheimer et al., 1996; Frazer et al., 2012), encouraging them to work harder (Brown and Dev, 1997; Croonen and Brand, 2015) and improving customer performance (Yu et al., 2012).

To promote training as a key aspect in the franchisor-franchisee relationship satisfaction, this study follows a more innovative approach by introducing a philosophy of internal customer orientation: an internal marketing (IM) approach. IM represents the managerial philosophy that commits to produce fair value for its employees, through which relationships between employees and managers are effectively managed, with the ultimate goal of creating superior customer value (Gounaris, 2006; Panigyrakis and Theodoridis, 2009; Tortosa-Edo et al., 2015). In this line, in the franchise literature, several studies have identified the franchisee as a key employee or internal customer of the system (King et al., 2013; Kim et al., 2020). In this regard, the franchisees perform the service on behalf of the franchisor, who delegates decision-making to them (King et al., 2013). Moreover, franchisees are responsible for implementing the strategies as designed by the franchisor and for managing direct contact with external customers (Brown and Dev, 1997). With the aim that the franchisees contribute to the franchise success, the franchisor must establish and manage a mutual, solid and lasting relationship (Kim et al., 2020), assisting them through actions that respond to their needs (Lee et al., 2015), and all this based on a focus on the franchisee as a key resource. This approach is built on IM philosophy, which suggests satisfying internal customer needs favours, providing more value to external customers (Ahmed and Rafiq, 2003; Mukherjee and Malhotra, 2006; Bermúdez-González et al., 2016).

Despite all the above, only a few works have addressed the IM in the franchise system (King et al., 2013; Merrilees and Frazer, 2013; Rashid and Ghose, 2015; Yang, 2015). Although the literature has recognized the relevant role of training in franchise success (Choo and Bowley, 2007; Ioanna and Maria, 2013), its research as a key practice of IM programmes has focused on service contexts other than franchising (Lings and Greenley, 2005; Gounaris, 2008; Kaur et al., 2009; Bermúdez-González et al., 2016). In addition, while most studies address IM from a behavioural perspective, authors such as Gounaris (2006) and Lings and Greenley (2005) have pointed to the need to explore the cultural perspective as well. Therefore, this study contributes to the franchise literature by increasing the scarce research on IM in the franchise system, and also by integrating a cultural perspective of IM, which has not been addressed, as far as the authors know, in this context.

Considering these arguments, the main objective of this paper is to analyse the role of training in enhancing franchisor-franchisee relationship satisfaction, and its influence upon customer performance, all driven by an IM culture. The remainder of this paper is structured as follows. The theoretical framework is developed, and the hypotheses of the proposed model are stated, 
after which a detailed, methodological approach is presented. The data are then analysed, and the results are reported. Finally, the conclusions, theoretical and practical implications for franchise system and future research are presented in the last section of this paper.

\section{Theoretical background}

The social exchange theory (SET) is adopted as the theoretical basis in this study. This theory has been widely used by researchers to analyse business-to-business relational exchange (Lambe et al., 2001; Yu et al., 2020) and, in particular, in the franchise literature to explain the franchisor-franchisee relationship in a complex context such as the franchise system (for a review, see Jang and Park, 2019). The presentation of this conceptual framework serves as a basis for the development of the hypotheses.

Traditionally, the SET has focused on the social relationships between employees and the employer organization (Cropanzano and Mitchell, 2005). As stated by Blau (1964), advantageous and fair transactions generate solid relationships which produce effective work behaviours and positive employee attitudes, resulting in the formation of long-term social patterns. This theory proposes that actions made to promote a successful exchange depend on the perception of reward in the reactions of the partners, which, in turn, supports and nurtures mutually gratifying transactions and relationships (Cropanzano et al., 2017). Hence, in the context of franchise systems, both parties aim to obtain economic and social results from each transaction developing a relationship based on mutual trust and collaboration (Altinay et al., 2014a).

The literature also indicates that SET could be used as a theoretical foundation to explain the development of IM in organizations, especially in the service sector, in order to attract, motivate and retain the most qualified employees (Berry and Parasunaman, 1991). Based on this theory, Yu et al. (2020) point out how IM highlights the value that employees have for the company, and thus meeting their needs becomes key for the organization. Therefore, if the company adequately satisfies employees' needs, they will respond by developing favourable behaviours to match it (Boukis et al., 2014), which can lead to improved organizational performance (Yu et al., 2020). On the basis of the SET framework, this study proposes a set of hypotheses to analyse the key role of the IM in improving the franchisor-franchisee relationship and its effects on organizational performance within the complex context of franchising.

\section{The relationship between IM culture and training relevance}

Various authors in the IM literature point out the need for a value system to guide the company in developing behaviours that meet the needs of its employees, and ultimately lead to greater value to the customer (Lings, 2004; Lings and Greenley, 2005; Gounaris, 2006; Gounaris et al., 2010). This value system represents the cultural aspect of IM by considering people to be the organization's most valuable asset, which can influence satisfaction and loyalty of this key resource (Lings and Greenley, 2005; Peltier et al., 2013). This idea is supported by Boukis (2019) when stating that the organization must be strategically oriented towards satisfying the needs of its internal customers by offering them greater value. This strategic orientation will nourish the organization, bearing the fruit of favourable behaviours by its workers in response to the higher perceived value (Berry, 2016). Thus, the development of this IM philosophy arises from the management's commitment to the implementation and dissemination of these values and beliefs, in which employee satisfaction becomes a key aspect for the progress of the organization (Lings and Greenley, 2005; Gounaris, 2006; Panigyrakis and Theodoridis, 2009; Gounaris et al., 2010). In order for this philosophy to be effectively demonstrated to all members of the company, it must be transformed into observable behaviour that is oriented towards satisfying the employee, which can be achieved through human resource practices (Domínguez-Falcón et al., 2017). Among such human resource practices, Varey (1995) and Grönroos (2000) point to training as the key 
component of an IM programme. In this line, this practice has been recognized as one of the most important IM tools to satisfy the employees of service companies (Mosahab et al., 2011) and as a key element in the success of the innovative services offer (Avlonitis and Papastathopoulou, 2001). Through training, companies get employees to have a clear vision of their value to the organization (Bansal et al., 2001), transmitting them the relevance of performing an excellent service and the necessary knowledge to provide quality customer service (Malhotra and Mukherjee, 2004; Tsai and Tang, 2008). According to Tsai and Tang (2008), employees will be able to meet customer needs if they have the knowledge and capabilities to deal more effectively with customers. Thus, within the framework of the IM philosophy, it is critical that employees perceive that the training received is tailored to their specific needs (Hogg et al., 1998; Tsai and Tang, 2008; Vance et al., 2013) and that it is especially important for them to be able to do their work. Training relevance is related to trainee motivation and consists of certain perceptions that the trainee has about training and its usefulness, which most likely may have been formed even before participating in it (Facteau et al., 1995; Sahoo and Mishra, 2019). Therefore, to promote participants' perception of the relevance of training courses for their work, trainers should clearly communicate in advance the potential benefits, content and expected outcomes of the training courses (RentaDavids et al., 2014). This would improve the transfer of learning and the impact of training.

Based on the above arguments and within the franchise context, it can be assumed that when franchisors develop an IM culture, they consider all their members, and especially the franchisees, to be a valuable asset to the system. Berry's (2016) study points out that when internal customers perceive this value, they become more sensitive to the organization's efforts. Based on this idea, the franchisees, as internal customers, can perceive that the franchisers, putting into practice the IM philosophy, have designed the training programmes according to their specific needs, and therefore they consider them relevant. Training provided by franchisors allows franchisees an opportunity to achieve the knowledge and skills related to operational aspects such as routines, procedures and tasks necessary to manage a new business (Michael, 2000; Chien, 2014; Gillis et al., 2014). The franchisor must persuade franchisees of the benefits of attending trainings from time to time so that they can implement newly designed, user-friendly business practices (Barthélemy, 2008). According to these arguments, $\mathrm{H} 1$ is formulated as follows:

H1. The IM culture has a positive effect on training relevance.

\section{Training relevance and training transfer behaviour}

As mentioned above, one of the major concerns within the field of training research is the extent to which trainees' behaviour actually changes once they return to their work context (Blume et al., 2010). In this regard, Blume et al. (2010, p. 1,066) point out that "in organizational contexts, original learning in a training experience is rarely adequate to render that training effective". In their seminal work, Baldwin and Ford (1988) echo other authors who had a contrasting point of view, namely, that when managers believed in the value of training, there was a greater chance that attendees would eventually apply the skills learned in their daily work. This training relevance perception derives from the trainee's internal recognition that there is an existing need to improve performance and that the knowledge and skills presenting in training will enable the achievement of this improvement (Burke and Hutchins, 2007).

Training relevance is among many antecedents of training transfer that Baldwin and Ford (1988) have included in their model (for a review, see Burke and Hutchins, 2007). Training relevance has been addressed by several authors who believe that the reputation of the training programme and the training department directly and indirectly influences training transfer behaviours (Facteau et al., 1995; Tsai and Tai, 2003). Similarly, Sahoo and Mishra (2019) find that the perceptions of the trainees, among which is the reputation of the training, 
are positively related to the self-motivation required to actually transfer what has been learned. If the trainees think that the organization's training programmes are of high quality and are capable of developing the necessary skills for their success at work, this positively influences their levels of motivation towards training, which affects the level of training transfer (Facteau et al., 1995; Burke and Hutchins, 2007). More specifically, the transfer of learning is positively influenced by the trainees' perceptions regarding content relevance for effective job performance (Gegenfurtner et al., 2009; Renta-Davids et al., 2014). When the trainees trust that the programme will convey useful, proven and appropriate ideas to them, they are more likely to try to use those ideas on the job (Yelon et al., 2013). Conversely, if the trainee does not perceive the training as relevant, once the training has been completed, it is unlikely that he/she will use the knowledge and skills presented which were intended to be transmitted into his/her daily work experience (Axtell et al., 1997). For the authors, training relevance has been shown to positively affect skill transfer in the short term and indirectly affect skill transfer in the long term. Finally, Renta-Davids et al. (2014) suggest that it is imperative to design training programmes based upon the trainees' needs and provide them with concrete benefits, and clearly inform the trainees about these benefits to influence their commitment to and level of transfer.

Thus, trainees should perceive that training programmes are valuable, necessary and beneficial, because this increases their motivational levels to participate in training activities (Tsai and Tai, 2003) as well as impacting their attitudes towards training transfer (Turab and Casimir, 2015). In light of these considerations, the following hypothesis is formulated:

H2. Training relevance has a positive effect on training transfer behaviour.

\section{Training transfer behaviour and franchisor-franchisee relationship satisfaction}

The role of knowledge transfer within the context of the franchisor-franchisee relationship is recognized in the literature (Brookes and Altinay, 2017). In this sense, Wickert and Herschel (2001) consider training programmes as a successful way to achieve the internal transfer of knowledge. In fact, the authors state that "in order to transfer tacit knowledge, training seems to be the only successful approach" (Wickert and Herschel, 2001, p. 330). Barthélemy (2008) has also addressed this issue within the context of the franchisor-franchisee relationship, underlining that training is the ideal way by which tacit knowledge may be transferred, while operational manuals transmit explicit franchise knowledge. In fact, franchisees rated a knowledge transmitted during training to be of a higher value than that received through operating manuals (Minguela-Rata et al.,2010). Thus, it is clear to see how important a role the transfer of knowledge plays between the partners of the franchise relationship. Franchisors provide specialized knowledge of a proven business system, while franchisees provide knowledge of the local market which fosters network growth (Altinay et al., 2014a; Weaven et al., 2014b). Therefore, the success of the franchisee's activity depends on the support of the franchisor (e.g., training assistance), whose success also depends on the good results of the former which acts in the operational management of the business (Jang and Park, 2019). As these authors have pointed out, the franchisor's performance depends on the performance of the franchisees and on the quality of the intrinsic relationship between both parties, so that both can attain a win-win situation.

However, although the transfer of knowledge in both directions is important, the flow of knowledge from the franchisor to the franchisee, which involves investing in training to ensure the efficient operation of a franchise unit, is the key to ensuring the concept of proven business (Paswan et al., 2014). In this respect, Gillis et al. (2020) identify franchise management capabilities, such as knowledge-sharing routines and operational procedures, promote successful franchise relationships and enhance overall franchisee performance. Based on the SET, Brookes et al. (2015) state that by providing training on a regular basis, the 
franchisor leads the franchisee to perceive that the relationship maintained between them is both valuable and positive.

The effects of training as supplied by the franchisor on the franchisee show a positive correlation to affective response, that is, suggest a heightened level of relationship satisfaction (Frazer et al., 2012). This concept refers to the degree by which franchisees perceive that franchisors meet or exceed their economic and psychological expectations regarding their shared relationship (Davies et al., 2011). In this sense, several studies have shown how the franchisor's support is directly linked to satisfaction within the franchise relationship (Gassenheimer et al., 1996; Weaven et al., 2014a). Through internal training, franchisors can vastly minimize unproductive work behaviours within the franchised units, improving the quality of the franchise relationship (Dant et al., 2013). Training promotes higher levels of engagement by the franchisee with the franchisor organization, and fosters greater adherence to the system as designed by the franchisor (Michael, 2000). However, the author also warns of the "risk of opportunism through free riding by the franchisee" (Michael, 2000, p. 498). In this sense, the mere fact that training is being provided by the franchisor does not guarantee that franchisee behaviour is in line with franchisor guidelines, even if some learning has taken place. In this regard, Gegenfurtner et al. (2009, p. 125) have highlighted how "the transfer of learning from training programs to applications in the workplace determines the effectiveness of human resource development interventions". The franchisee's training transfer behaviour indicates franchisee's actual compliance with the franchisor's business model, designed and transmitted through training, and ensures that operations are carried out as intended (Castrogiovanni and Kidwell, 2010), resulting in a positive impact on the bottom line (Choo and Bowley, 2007). From the franchisor's perspective, the achievement of this goal, in alignment with franchisee cooperation, will positively affect the perception of the shared relationship. On the other hand, when joining a franchise, franchisees do look for some advantages, such as training, in pursuit of the acquisition of knowledge, skills and technical expertise (Choo and Bowley, 2007). When franchisees apply what they have learned to their work environments, this advantage becomes real and helps them achieve their business objectives, which, in turn, influences their level of satisfaction with the franchisor-franchisee relationship. According to these arguments, the following hypothesis is proposed:

H3. Training transfer behaviour positively affects franchisor-franchisee relationship satisfaction.

\section{Training transfer behaviour and customer performance}

Examination of franchise-focused literature has provided evidence of the importance of training programmes on franchise system performance (Larson, 2003). For this reason, training transfer should be addressed to all levels of the franchisee organization (i.e. managers, assistant managers and employees) (Justis and Chan, 1991). Specifically, the success of the franchise depends on the franchisor's ability to transfer knowledge through training, among other means, as well as the franchisee's ability to assimilate and apply it correctly (Minguela-Rata et al., 2010). In this sense, franchise performance depends largely on the cooperation between the franchisor and its franchisees to maximize the value of the brand and to ensure consistency in the production of products and services (Pitt et al., 2003).

Based on the training transfer literature perspective, training transfer remains the fundamental challenge of organizational training, since it holds the key to significant changes in work performance (Blume et al., 2010). The work of Rouiller and Goldstein (1993) confirms that the training transfer leads to better performance, in terms of quality and service, by the employees within the units of a franchised chain. According to Yelon et al. (2013), while observing transfer of training from a broader perspective which includes the different applications of what has been learned, training transfer can lead trainees to use the adopted 
knowledge and skills to improve their decision-making processes. Along these lines, Chien (2014) has verified that training provided by the franchisor enables the franchisee to make effective decisions which stimulate the improvement of unit performance.

Traditionally, franchises have opted to train, develop and transfer knowledge through operating manuals, marketing plans and standard procedures to franchisees which serve as operational guides to improve the business (Ioanna and Maria, 2013). Through these knowledge-based investments, franchisors have improved brand image, encouraging franchisees to comply with the business concept (Paswan et al., 2014; Badrinarayanan et al., 2016). In addition, franchisors must develop trust with the franchisees to ensure that policies and system standards are met (Croonen and Brand, 2015), to avoid reducing the performance of individual franchisees as well as the entire franchise system (Davies et al., 2011). In fact, the need for continual training has been established, extending beyond the initial stage of the franchisor-franchisee relationship, in order to improve franchisee capabilities, favouring an ongoing basis whereby high quality of the relationship and financial performance can be maintained (Chiou et al., 2004; Altinay et al., 2014a; Varotto and Parente, 2016). In summary, by utilising the franchisor's training programmes, franchisees can acquire valuable know-how and management skills to operate their businesses successfully, and thus improve customer satisfaction (Choo and Bowley, 2007; Chien, 2014). Based upon these arguments, the following hypothesis is formulated:

H4. Training transfer behaviour positively affects customer performance.

\section{Franchisor-franchisee relationship satisfaction and customer performance}

The internal exchange between franchisor and franchisee has been characterised as complex, difficult to manage, continuous and long-lasting, which must be cared for as it is crucial to the success of the franchise system (Watson and Johnson, 2010; Varotto and Parente, 2016; Kalargyrou et al., 2018). When franchisees are not happy with the relationship, the results of the system worsen, increasing their tendency to display opportunistic behaviour (Roh and Yoon, 2009; Watson and Johnson, 2010). In this situation, franchisees are less likely to implement franchisor-designed strategies (Jang and Park, 2019) and more likely to make harmful decisions regarding their customer (lower quality of customer service, overpricing, etc.), which normally results in poor brand quality perception and worsened organizational performance (Kidwell et al., 2007). On the contrary, relationship satisfaction significantly reduces the franchisee's opportunistic behaviour and even inspires the desire for further growth and success in his/her franchisee unit (Brookes et al., 2015). A higher level of satisfaction improves franchise performance, leading to a successful business relationship (Fernández-Monroy et al., 2018). Many authors (Roh and Yoon, 2009; Nijmeijer et al., 2014; Kalargyrou et al., 2018) point out that the more satisfactory the relationship, the greater degree of franchisee willingness to remain in the franchise system.

According to the SET, franchisees who subjectively consider their relationship with the franchisor valuable show a higher degree of compliant behaviour (Brookes et al., 2015). Thus, building sustainable franchisor-franchisee relationships is crucial, with relational satisfaction being an essential ingredient for franchise success (Jang and Park, 2019). Franchisee satisfaction generates a great impact on the brand, enhancing the opening of new units and increasing the overall performance of the franchise chain (Dickey et al., 2007; Davies et al., 2011). Likewise, Evanschitzky et al. (2011) have shown that franchisee satisfaction influences customer satisfaction indirectly, through the satisfaction of the unit's employees, which favours customer loyalty. Therefore, healthy franchisor-franchisee relationships encourage the franchisee to make greater strides in consolidating the brand, enhancing market position (Nyadzayo et al., 2011; Ghantous and Das, 2018). On this basis, the following hypothesis is established: 
H5. Satisfaction with the franchisor-franchisee relationship positively affects customer performance.

Figure 1 shows the proposed model that collects the hypotheses of this study.

\section{Methodology}

Context, sample and franchise profile

This research has been carried out in Spain based on the franchise system, whose business model has shown to have a major impact on employment. The relevance of the franchise system could be seen in 2019 employment data which show that franchises effectively employed 294,231 people. According to the Annual Report "Franchising in Spain. Report 2020" edited by the Spanish Franchise Association (AEF, Spanish acronym) during 2019, the franchise system slightly increased in terms of the number of networks, branches and new jobs generated (Spanish Franchise Association, 2020).

Data for the study were collected through primary sources. The population of the study was composed of franchise systems operating in Spain, identified through the information provided by the 2019 report of the AEF, as well as by the 2018 Franchise Guide published by the business magazine Emprendedores. Finally, the total population was 626 franchises. The online questionnaire was generated after an extended literature review. Several trials were conducted, resulting in minor adjustments in the wording of some items. The invitations to participate in the study were sent by email to the franchisors, whose collaboration was also encouraged by the AEF. After two weeks, the franchisors were contacted by phone to explain the study in more detail and to encourage them to participate. Accordingly, they were then sent the link to the online questionnaire. After three rounds of calls, 1,110 additional emails were dispatched to get more franchises involved in the research. In addition, the franchisors were also asked to send the franchisees a link to the questionnaire. Only the researchers would be able to access the information collected in the questionnaires, which would be analysed in a confidential and aggregated manner. After this follow-up period, 162 responses were received, resulting in a final sample of 157 , once the responses with missing values were eliminated. The response rate was $25 \%$, which is not unusual in studies developed at organizational level (Baruch and Holtom, 2008) and research in the franchise field (Dickey et al., 2007; Chien, 2014; Lee et al., 2015; Fernández-Monroy et al., 2018).

The franchises participating in the study operate in various sectors of activity, and especially in the area of services. In particular, the participants are distributed by sector as follows: $26.75 \%$ operate in "Hotel/restaurant", $17.20 \%$ in "Health and beauty", $8.92 \%$ in "Education", $7.01 \%$ in "Real estate agencies", $7.01 \%$ in "Food/supermarkets", $5.10 \%$ in "Fashion", 3.18\% in "Telecommunications and new technologies", 1.91\% in "Travel agencies", $10.83 \%$ in other service franchises and $12.10 \%$ in other retail branches. Regarding the profile of key informants, $66.9 \%$ were male and $33.1 \%$ female; $62.2 \%$ were between 31 and 50 years old (30.1\% between 31 and 40, and $32.1 \%$ between 41 and 50 ); and $74.4 \%$ had

Figure 1.

Proposed model

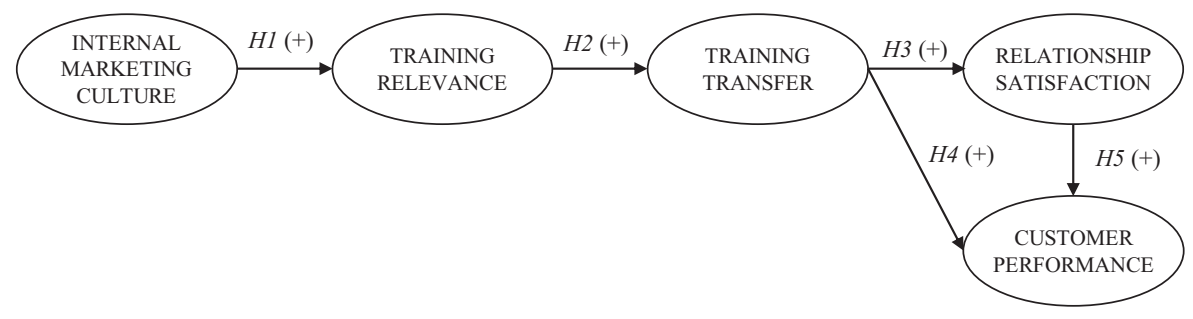


attained higher education levels ( $46.8 \%$ had an undergraduate degree and $27.6 \%$ had either a master's degree or completed doctoral studies).

\section{Variables}

The questionnaire was designed to allow for the construction of seven-point Likert-type scales ranging from 1 (strongly disagree) to 7 (strongly agree), in order to measure the variables included in the theoretical model. The IM culture variable is measured using a six-item scale based on that of Domínguez-Falcón et al. (2017). The training relevance scale is composed of three items adapted from Tannenbaum (1997) and Xiao (1996). Training transfer behaviour is measured through three items extracted and adapted from the scale developed by Xiao (1996). Relationship satisfaction is measured through four items extracted from the scale developed by Boyle and Dwyer (1995) and Fernández-Monroy et al. (2018). Customer performance is measured through four items adapted from the scale developed by Sanzo et al. (2012).

\section{Research method}

The scales used in this study contain a certain exploratory character. As far as the authors know, scales relative to IM culture have not been used within the framework of the franchisorfranchisee relationship. Similarly, aspects relating to training transfer and its antecedents have not been applied in this franchise context. For this reason, an exploratory analysis of these variables was made using IBMSPSS Statistics 26 software, followed by a confirmatory factorial analysis using EQS 6.3 software (Lloret-Segura et al., 2014). Cronbach's alphas have been used to determine the reliability of the scales (Hair et al., 1999).

Structural equation modelling (SEM) was used to test the hypotheses because the model where they are included represents relationships among multiple prediction and criterion variables, with mediating variables, and in these cases SEM is an adequate tool for analysing these relationships (Chin, 1998). The model is estimated by using maximum-likelihood with robust statistics based on the covariance matrix of the variables included. Research hypotheses are checked based on the significance and weights of the estimated causal pathways. This methodology involves studying two distinct scenarios: the measurement model and the structural model (Anderson and Gerbing, 1988; Hair et al., 1999). Lastly, following the recommendation of Chin (1998), Appendix shows both the means and the deviations of the variables, as well as its correlation matrix.

\section{Data analysis and results \\ Measurement model}

Exploratory factor analysis (EFA). In order to carry out a primary evaluation of the factor structure, three exploratory analyses were carried out: the first was dedicated to IM culture, the second on variables related to training and the third was based on variables associated with performance. In this way, variables that could present greater correlations a priori have been analysed in the same EFA, in order to check their dimensionality. As shown in Table 1, the EFA for IM culture showed a single factor (Cronbach's alpha $=0.881$ ).

The EFA for the training-related variables revealed the existence of two factors: "Training Relevance", comprises three items (Cronbach's alpha $=0.853$ ); "Training Transfer" comprises of three items (Cronbach's alpha $=0.891$ ). Cronbach's $\alpha$ of the entire scale is 0.899 (Table 2).

Finally, the EFA of the variables related to performance showed the existence of two factors: the first, termed "Relationship Satisfaction", comprises four items (Cronbach's

\section{Training as an internal marketing tool}

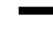


JSTP

\begin{tabular}{|c|c|c|}
\hline Variables & Com & $\begin{array}{c}\text { Factor } 1 \\
\text { load }\end{array}$ \\
\hline IMC1. In our company, the well-being of all franchisees is a concern & 0.701 & 0.837 \\
\hline $\begin{array}{l}\text { IMC2. In our company, there is a belief that it is important to look for the happiness of } \\
\text { the franchisees in their work }\end{array}$ & 0.701 & 0.837 \\
\hline IMC3. In our company, one of the main objectives is to keep the franchisees satisfied & 0.669 & 0.818 \\
\hline IMC4. In our company, we try to adapt to the personal needs of each franchisee & 0.665 & 0.815 \\
\hline $\begin{array}{l}\text { IMC5. In our company, it is important to understand the factors that affect franchisee } \\
\text { satisfaction }\end{array}$ & 0.617 & 0.785 \\
\hline IMC6. In our company, there is a belief that people are the most important resource & 0.494 & 0.703 \\
\hline Eigenvalue & \multirow{6}{*}{\multicolumn{2}{|c|}{$\begin{array}{l}3.847 \\
64.109 \\
0.875 \\
478.767(0.000) \\
0.881\end{array}$}} \\
\hline Total percentage of explained variance & & \\
\hline Kaiser-Meyer-Olkin measure & & \\
\hline Barlett's test of sphericity & & \\
\hline Cronbach's alpha & & \\
\hline Factor 1: IM culture & & \\
\hline
\end{tabular}

Table 1.

Exploratory factor

Factor 1: IM culture

\begin{tabular}{|c|c|c|c|}
\hline Variables & Com & $\begin{array}{c}\text { Factor } 1 \\
\text { load }\end{array}$ & $\begin{array}{c}\text { Factor } 2 \\
\text { load }\end{array}$ \\
\hline $\begin{array}{l}\text { TF1. In our company, franchisees have incorporated skills learned } \\
\text { during training into daily work activities }\end{array}$ & 0.821 & 0.875 & 0.235 \\
\hline $\begin{array}{l}\text { TF2. In our company, training has helped to improve the work } \\
\text { performance of the franchisees }\end{array}$ & 0.865 & 0.860 & 0.354 \\
\hline $\begin{array}{l}\text { TF3. In our company, the franchisees have used the skills acquired in the } \\
\text { training courses to improve business results }\end{array}$ & 0.791 & 0.784 & 0.421 \\
\hline $\begin{array}{l}\text { TR1. In our company, training is offered on a regular basis, so that } \\
\text { franchisees can develop their skills or abilities }\end{array}$ & 0.858 & 0.232 & 0.897 \\
\hline $\begin{array}{l}\text { TR2. In our company, training programmes are planned in advance and } \\
\text { according to future needs }\end{array}$ & 0.832 & 0.387 & 0.826 \\
\hline TR3. Training is adapted to the individual needs of each franchisee & 0.649 & 0.347 & 0.727 \\
\hline Eigenvalue & \multicolumn{2}{|l|}{4.027} & 0.788 \\
\hline Partial percentage of variance explained & \multirow{4}{*}{\multicolumn{2}{|c|}{67.125}} & 13.135 \\
\hline Total percentage of explained variance & & & 80.260 \\
\hline Kaiser-Meyer-Olkin measure & & & 0.853 \\
\hline Barlett's test of sphericity & & & $\begin{array}{r}608.679 \\
(0.000)\end{array}$ \\
\hline \multirow{3}{*}{\multicolumn{3}{|c|}{$\begin{array}{l}\text { Cronbach's alpha } \\
\text { Factor 1: Training transfer } \\
\text { Factor 2: Training relevance }\end{array}$}} & 0.899 \\
\hline & & & \\
\hline & & & \\
\hline
\end{tabular}

alpha $=0.919)$. The second, termed "Customer Performance", also comprises four items (Cronbach's alpha $=0.836$ ). Cronbach's $\alpha$ value of the entire scale is 0.853 (Table 3).

The potential downside of common method variance bias can be analysed by jointly including the items on the different scales to detect the existence of a single factor, which would explain most of the total variances. This single factor explains only $41.19 \%$ of the variance. Additionally, common-method bias testing was also evaluated by the statistical comparison of the five-factor measurement model $\left(\mathrm{SB} \chi^{2}=189.617 \mathrm{df}=160\right)$ to a one-factor measurement model $\left(\mathrm{SB} \chi^{2}=822.897, \mathrm{df}=170\right)$, as recommended by Podsakoff et al. (2003). 


\begin{tabular}{|c|c|c|c|c|}
\hline Variables & Com & $\begin{array}{l}\text { Factor } 1 \\
\text { load }\end{array}$ & $\begin{array}{c}\text { Factor } 2 \\
\text { load }\end{array}$ & \multirow{9}{*}{$\begin{array}{l}\text { raining as an } \\
\text { internal } \\
\text { marketing tool }\end{array}$} \\
\hline RS1. This relationship can be described as successful & 0.859 & 0.918 & 0.129 & \\
\hline RS2. Overall, we are very satisfied with the relationship we have & 0.859 & 0.913 & 0.158 & \\
\hline RS3. We are both completely happy with each other & 0.839 & 0.900 & 0.171 & \\
\hline $\begin{array}{l}\text { RS4. If we had to create a new relationship of these characteristics, we } \\
\text { would do business again with the same participating companies }\end{array}$ & 0.702 & 0.828 & 0.129 & \\
\hline \multirow{4}{*}{$\begin{array}{l}\text { CP1. Compared to our competitors, in recent years, the quality of the } \\
\text { service offered has greatly improved } \\
\text { CP2. Compared to our competitors, in recent years, the adaptation of } \\
\text { customer service has greatly improved } \\
\text { CP3. Compared to our competitors, in recent years, the company's image } \\
\text { has improved a lot } \\
\text { CP4. Compared to our competitors, in recent years, the satisfaction of our } \\
\text { customers has greatly improved }\end{array}$} & 0.763 & 0.139 & 0.863 & \\
\hline & 0.702 & 0.078 & 0.834 & \\
\hline & 0.627 & 0.090 & 0.786 & \\
\hline & 0.627 & 0.254 & 0.750 & \\
\hline Eigenvalue & \multirow{8}{*}{$\begin{array}{r}3.998 \\
49.979\end{array}$} & & 1.980 & \multirow{8}{*}{$\begin{array}{r}\text { Table } 3 . \\
\text { Exploratory factor } \\
\text { analysis for } \\
\text { performance-related } \\
\text { variables }\end{array}$} \\
\hline Partial percentage of variance explained & & & 24.753 & \\
\hline Total percentage of explained variance & & & 74.732 & \\
\hline Kaiser-Meyer-Olkin measure & & & 0.836 & \\
\hline Barlett's test of sphericity & & & $\begin{array}{r}778.143 \\
(0.000)\end{array}$ & \\
\hline Cronbach's alpha & & & 0.853 & \\
\hline Factor 1: Relationship satisfaction & & & & \\
\hline Factor 2: Customer performance & & & & \\
\hline
\end{tabular}

Results of this comparison show no evidence of common-method bias in the data as the onefactor model exhibited significant deterioration in $\mathrm{SB} \chi^{2}$ by 633.280 , $\mathrm{df}=10(p<0.01)$, showing the superiority of the five-factor model. Therefore, based on these two analyses, it can be considered that common method variance does not seem to be an issue in this particular study.

Confirmatory factor analysis (CFA). In order to confirm the robustness of the scales, three confirmatory factor analyses (CFA) were conducted. First, as Anderson and Gerbing (1988) have suggested, data were analysed to verify the fulfilment of the assumptions which recommend the use of SEM methodology. This analysis only showed the absence of multivariate normality, so maximum-likelihood estimation with robust statistics was used to address this question (Mueller, 1997). The CFA followed the same grouping of variables, as did the EFA.

The first CFA analyses the IM culture variable, showing that the estimates are significant and in the expected direction (see Table 4). The model shows satisfactory goodness-of-fit indicators, with a $p$-value of 0.066 for a Satorra-Bentler chi-square $\left(\mathrm{SB} \chi^{2}\right)$ of 16.020 , a robust RMSEA of 0.071 which is below the level of 0.08 and a robust CFI index of 0.973 which is above the recommended level of 0.9 (Schumaker and Lomax, 2010). In relation to this scale, content validity is assumed in light of reviewing source literature. Convergent validity is also assumed because standardized estimates were all higher than 0.5 , significant at $1 \%$ and in the right direction (Hair et al., 1999), with an average variance extraction (AVE) of 0.571 which exceeds 0.50 (Fornell and Larcker, 1981). Internal consistency of the scales has been proven since the composite reliability is above the minimum level of 0.6 and all indicators provide individual reliability greater than 0.3 (Bagozzi and Yi, 1988). 
JSTP

\begin{tabular}{lccccc}
\hline Dimensions & $\begin{array}{c}\text { Standardised } \\
\text { estimator }\end{array}$ & $Z$ & $R^{2}$ & $\begin{array}{c}\text { Composite } \\
\text { reliability }\end{array}$ & $\begin{array}{c}\text { Average variance } \\
\text { extracted }\end{array}$ \\
\hline IMC6 $\leftarrow$ IM culture & 0.615 & - & 0.379 & 0.888 & 0.571 \\
IMC5 $\leftarrow$ IM culture & 0.712 & 7.01 & 0.506 & & \\
IMC2 $\leftarrow$ IM culture & 0.809 & 6.53 & 0.655 & & \\
IMC3 $\leftarrow$ IM culture & 0.792 & 5.55 & 0.627 & & \\
IMC4 $\leftarrow$ IM culture & 0.778 & 5.92 & 0.605 & & \\
IMC1 $\leftarrow$ IM culture & 0.810 & 6.21 & 0.656 & & \\
\hline
\end{tabular}

Measures of goodness of fit ML

Measures of goodness of fit Ml robust

Table 4.
IM culture CFA results

$\chi^{2}=25.961 \mathrm{DF}=9 p=0.002 \mathrm{CFI}=0.964 \mathrm{RMSEA}=0.110$

$\mathrm{SB} \chi^{2}=16.020 \mathrm{DF}=9 p=0.066 \mathrm{CFI}=0.973$

RMSEA $=0.071$

The variables training relevance and training transfer are studied together in the second CFA. The model shows that all estimates are significant at $1 \%$ and in the expected direction (see Table 5). Goodness-of-fit indicators show to be satisfactory, with a $p$-value of 0.1440 for $\mathrm{SB} \chi^{2}$ of 12.1630 , a robust RMSEA of 0.058 and a robust CFI index of 0.987 . Content validity of this scale is assumed based on the review of source literature with respect to its design. With regard to convergent validity, all standardized estimates are higher than 0.5 , significant at $1 \%$ and in the right direction, with AVE values for both variables greater than 0.5 (see Table 6). The composite reliability of both scales is above 0.6 , and all indicators have an individual reliability greater than 0.3. Finally, to analyse discriminant validity of the scales, the square root of the AVE for each of the scales was calculated and then compared with the corresponding correlations of the latent variables

\begin{tabular}{lcccc}
\hline Dimensions & Standardised estimator & $Z$ & $R^{2}$ & Composite reliability \\
\hline TR3 $\leftarrow$ Training relevance & 0.688 & - & 0.474 & \\
TR1 $\leftarrow$ Training relevance & 0.847 & 11.37 & 0.718 & 0.862 \\
TR2 $\leftarrow$ Training relevance & 0.918 & 11.19 & 0.843 & \\
TF3 $\leftarrow$ Training transfer & 0.859 & - & 0.738 & \\
TF2 $\leftarrow$ Training transfer & 0.913 & 14.42 & 0.833 & 0.893 \\
TF1 $\leftarrow$ Training transfer & 0.798 & 10.40 & 0.637 & \\
\hline
\end{tabular}

Table 5.

Training related variables CFA results
Measures of goodness of fit $\mathrm{ML}$

$\chi^{2}=14.673 \mathrm{DF}=8 p=0.0066 \mathrm{CFI}=0.989$

RMSEA $=0.073$
Measures of goodness of fit $\mathrm{Ml}$ robust

$\mathrm{SB} \chi^{2}=12.163 \mathrm{DF}=8 p=0.1440 \mathrm{CFI}=0.987$

$\mathrm{RMSEA}=0.058$
Table 6.

Discriminant validity training-related scales

\begin{tabular}{lll}
\hline Dimensions & TR & TF \\
\hline TR: Training relevance & 0.823 & \\
TF: Training transfer & 0.753 & 0.857
\end{tabular}

Note(s): Square root of AVE is represented in the principal diagonal 
(Fornell and Larcker, 1981). As Table 6 indicates, the square root of every AVE is greater than the corresponding correlation.

The last CFA analyses variables related to performance are relationship satisfaction and customer performance. The resulting model shows a satisfactory overall fit, with a $p$-value of 0.6358 for $\mathrm{SB} \chi^{2}$ of 16.3197 , a robust RMSEA of 0.000 and a robust CFI index of 1.000 (see Table 7). Regarding these variables, the review of previously described literature guarantees content validity. Convergent validity is assumed since standardized estimates were all greater than 0.6 , significant at $1 \%$ and in the right direction, with AVE values for both scales greater than 0.5. Discriminant validity of the scales is shown because the square root of every AVE is greater than the corresponding correlation (see Table 8).

\section{Structural model}

Hypotheses were tested by means of the structural model shown in Figure 2. The necessary calculation was made regarding its statistical power based on sample size $(N=157)$, number of degrees of freedom ( $\mathrm{df}=165$ ) and alternative RMSEA (Alt. RMSEA $=0.08$ ), using Preacher and Coffman (2006) software. The results of this analysis show that this SEM model exceeds the recommended lower limit of $80 \%$ for research in the behavioural sciences (Cohen, 1988).

The model goodness-of-fit indices fall within accepted thresholds. $\mathrm{SB} \chi^{2}$ normalized by degrees of freedom is 1.34, which is less than the upper limit of 3 as recommended by Bagozzi and $\mathrm{Yi}(1988)$. Nevertheless, the $p$-value for the $\mathrm{SB} \chi^{2}$ is 0.002 and is below the minimum level of 0.05 (Schumaker and Lomax, 2010). The model also shows positive figures regarding other fit indices, as the robust RMSEA is 0.047 which is below the most rigorous thresholds (Byrne, 2006). In addition, following MacCallum et al. (1996) who advocate the use of confidence intervals to measure the model fit, the $90 \%$ RMSEA confidence interval was checked to verify that its upper limit (0.062) falls below the 0.08 threshold. The values of the robust CFI index

\begin{tabular}{lcccc}
\hline Dimensions & Standardized estimator & $Z$ & $R^{2}$ & Composite reliability \\
\hline RS4 $\leftarrow$ Relationship satisfaction & 0.746 & - & 0.556 & \\
RS3 $\leftarrow$ Relationship satisfaction & 0.879 & 11.29 & 0.772 & 0.926 \\
RS1 $\leftarrow$ Relationship satisfaction & 0.924 & 10.80 & 0.853 & \\
RS2 $\leftarrow$ Relationship satisfaction & 0.922 & 11.01 & 0.850 & \\
CP4 $\leftarrow$ Customer performance & 0.700 & - & 0.490 & \\
CP3 $\leftarrow$ Customer performance & 0.689 & 7.94 & 0.475 & 0.841 \\
CP1 $\leftarrow$ Customer performance & 0.853 & 10.26 & 0.727 & \\
CP2 $\leftarrow$ Customer performance & 0.769 & 8.64 & 0.592 & \\
\hline
\end{tabular}

MEASURES OF GOODNESS OF FIT ML $\chi^{2}=25.305 \mathrm{DF}=19 p=0.1507 \mathrm{CFI}=0.992$ RMSEA $=0.046$
Training as an internal marketing tool

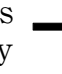


JSTP

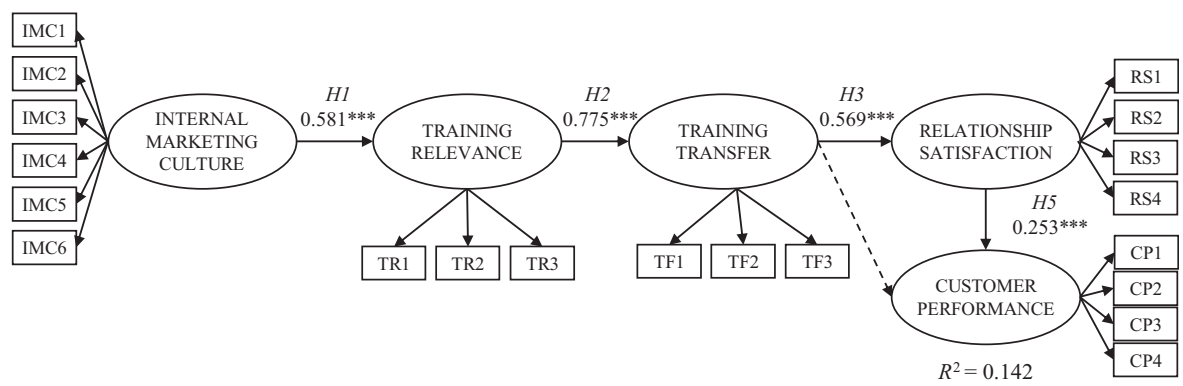

Figure 2.

Structural model analysis: results

\begin{tabular}{l|c|c|}
\cline { 2 - 3 } Note(s): Standardized regression weights & MEASURES OF GOODNESS OF FIT ML & MEASURES OF GOODNESS OF FIT ML ROBUST \\
\cline { 2 - 3 }$* * * p<0.01$ & $\mathrm{SB} \chi^{2}=280.652 \mathrm{df}=165 \mathrm{SB} \chi^{2} / \mathrm{df}=1.70 p=0.00000$ & $\mathrm{SB} \chi^{2}=222.0051 \mathrm{df}=165 \mathrm{SB} \chi^{2} / \mathrm{df}=1.34 p=0.00204$ \\
Bentler-Bonett NNFI $=0.934 \mathrm{CFI}=0.943$ & Bentler-Bonett NNFI $=0.951 \mathrm{CFI}=0.957$ \\
$\cdots \cdots \cdots \cdots$ & Non significant & RMSEA $=0.047 \% 90$ INT.RMSEA $(0.029,0.062)$ \\
\hline
\end{tabular}

(0.957) and Bentler-Bonett non-normed fit index (0.951) indicate a superior fit (Byrne, 2006). Finally, the squared multiple correlation reflects that the proposed model explains a substantial proportion of customer performance $\left(R^{2}=0.142\right)$ (see Figure 2).

Review of the standardized estimators and the critical ratios shows that IM culture has a positive and significant relationship with training relevance $(0.581, p<0.01)$, supporting hypothesis 1 . Hypothesis 2 was also validated, due to the existence of a positive and significant relationship between training relevance and training transfer $(0.775, p<0.01)$ as evidenced. The results allow for the validation of Hypothesis 3 , which postulated the positive relationship between training transfer and relationship satisfaction $(0.569, p<0.01)$. However, training transfer does not seem to have a direct relationship with customer performance, so Hypothesis 4 cannot be validated. Finally, relationship satisfaction has a positive and significant relationship with customer performance $(0.253, p<0.01)$, allowing for the validation of Hypothesis 5 .

Since the model tested presents several mediating relationships, it is appropriate to analyse the direct and indirect effects between the included variables (see Table 9). Thus, IM culture has a strong direct effect (0.581) on training relevance (0.581), and indirect effects on training transfer (0.451), relationship satisfaction (0.257) and customer performance (0.142). Results also show a strong direct effect (0.775) of training relevance on training transfer, and indirect effects on relationship satisfaction (0.441) and customer performance $(0.243)$.

\begin{tabular}{lccc}
\hline Dimensions & Direct effect & Indirect effect & Total effect \\
\hline Internal marketing culture $\rightarrow$ training relevance & 0.581 & 0.000 & 0.581 \\
Internal marketing culture $\rightarrow$ training transfer & 0.000 & 0.451 & 0.451 \\
Internal marketing culture $\rightarrow$ relationship satisfaction & 0.000 & 0.257 & 0.257 \\
Internal marketing culture $\rightarrow$ customer performance & 0.000 & 0.142 & 0.142 \\
Training relevance $\rightarrow$ training transfer & 0.775 & 0.000 & 0.775 \\
Training relevance $\rightarrow$ relationship satisfaction & 0.000 & 0.441 & 0.441 \\
Training relevance $\rightarrow$ customer performance & 0.000 & 0.243 & 0.243 \\
Training transfer $\rightarrow$ relationship satisfaction & 0.569 & 0.000 & 0.569 \\
Training transfer $\rightarrow$ customer performance & 0.170 & 0.144 & 0.314 \\
Relationship satisfaction $\rightarrow$ customer performance & 0.253 & 0.000 & 0.253
\end{tabular}

Table 9.

Direct, indirect and total effects
Note(s): Total and indirect effects were all significant. Directs effects were all significant except the effect of training transfer on customer performance 
Regarding training transfer, it has a significant direct effect on relationship satisfaction (0.569), but it does not have a significant direct effect on customer performance, although it has a significant indirect effect on this last variable (0.144). Finally, relationship satisfaction presents a direct effect on customer performance (0.253).

This study has taken on a certain exploratory character in regard to inter-dependent relationships as it integrates different theoretical frameworks which, to date, have not been linked nor examined. For this reason, with the intention of presenting alternative models that might fit more closely together, a model is estimated in which only the significant relationships of those initially proposed are retained, in order to be subsequently compared with two nested models (see Figure 3). In Model A, an interdependent relationship between IM culture and relationship satisfaction has been added to the proposed model. In Model B, a relationship between training relevance and relationship satisfaction was incorporated. The fit indices of these models and the tests of the differences between these alternative models as well as that of the proposed model are shown in Table 10.

Alternative Model A, which proposes a relationship between the IM culture and relationship satisfaction, generates a scaled difference of the $\mathrm{SB} \chi^{2}$ of 26.56 , which makes it a significant finding (greater than 3.84, $p>0.05$ ) (Satorra and Bentler, 2001). Therefore, this relationship improves the model fit. In fact, it can also be observed that for this model the $\mathrm{SB} \chi^{2}$ has a probability greater than 0.05 . However, by adding the relationship of training relevance and relationship satisfaction on alternative Model B, it is not significant.

\section{Conclusions and implications}

In conclusion, it can be said that although the strengthening of franchisor-franchisee relationship has been of great research interest in recent years, it has become necessary to advance this analysis, based on the perspective of IM culture. In this study, scientific knowledge has been generated, indicating how IM culture responds to the needs of franchisees through training, which enhances franchisor-franchisee relationship satisfaction and leads to better customer performance within the franchise.

The added value of this paper is to focus on the role of training, in terms of "training relevance" and "training transfer", for the consolidation of franchisor-franchisee relationship and customer performance, promoted by an IM culture. From this innovative integration of different literature related to IM, training and franchising, this study has made several theoretical and practical contributions to franchise-based literature.

\section{Theoretical implications}

First, it is important to present the novelty of the proposed theoretical model that integrates issues related to IM, training and franchise literature. On the basis of this exploratory model, this research examines the role of IM as a managerial philosophy within the franchise context. This philosophy enables the franchisee to become a critical asset that must be satisfied in order to contribute to the franchise system success. Thus, one of the theoretical contributions of the paper is based on the idea that developing an IM culture could constructively strengthen the franchise system, beyond purely contractual obligations, which literature has shown to be sometimes insufficient to establish satisfactory relationships between the parties. Considering the IM as culture, the present study deeply analyses the franchise system by treating the franchisee as an internal customer. This innovative approach represents an interesting alternative analysis of this organizational environment's complex relationship. Previous attempts (e.g., Nyadzayo et al., 2011) have been made to explain how a healthy franchisor-franchisee relationship could help generate better performance beyond the initial contractual relationship. Although researchers in this field attest to the need to generate an 


\section{JSTP}

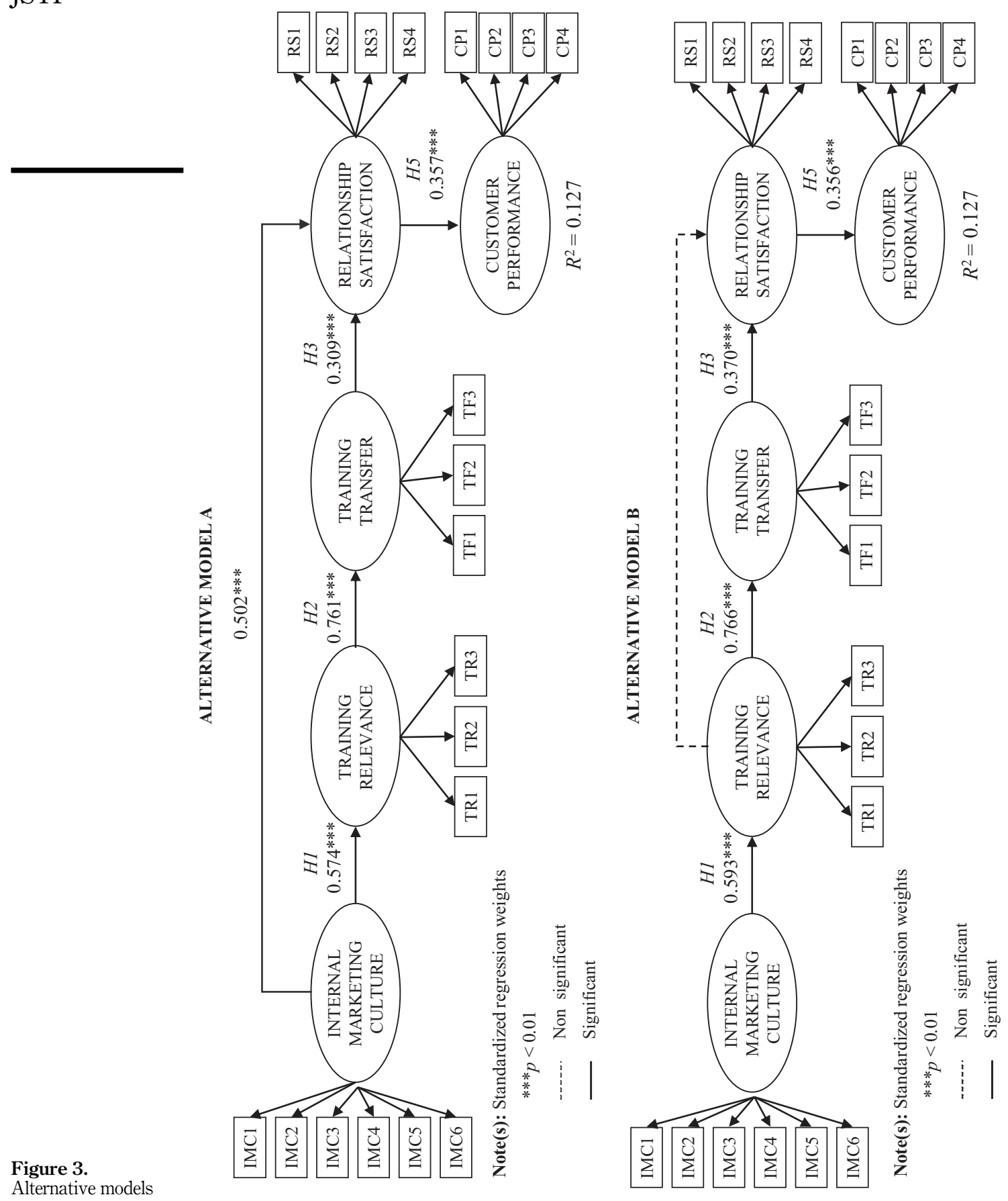




\begin{tabular}{|c|c|c|c|c|c|c|c|}
\hline Model & $\begin{array}{r}\text { Meas } \\
\mathrm{SB} \chi^{2}(\mathrm{~d} . \mathrm{f}) \\
\end{array}$ & $\begin{array}{l}\text { ares of } g c \\
p \\
\end{array}$ & $\begin{array}{l}\text { odness of } \\
\text { RMSEA } \\
\end{array}$ & $\begin{array}{l}\text { it ML robust } \\
\text { Bentler- } \\
\text { Bonett NNFI } \\
\end{array}$ & CFI & $\begin{array}{c}\Delta \mathrm{SB} \chi^{2} \\
\text { (d.f. difference) }\end{array}$ & \multirow[t]{5}{*}{$\begin{array}{r}\text { Training as an } \\
\text { internal } \\
\text { marketing tool }\end{array}$} \\
\hline $\begin{array}{l}\text { Theoretical model (with } \\
\text { significant relationships } \\
\text { only) }\end{array}$ & 223.7418 (166) & 0.0018 & 0.047 & 0.950 & 0.957 & - & \\
\hline $\begin{array}{l}\text { Alternative model A } \\
\text { IM culture - relationship } \\
\text { satisfaction }\end{array}$ & 195.0895 (165) & 0.0546 & 0.034 & 0.974 & 0.977 & $26.56^{*}(1)$ & \\
\hline $\begin{array}{l}\text { Alternative Model B } \\
\text { training relevance - } \\
\text { relationship satisfaction }\end{array}$ & 220.7857 (165) & 0.0024 & 0.047 & 0.952 & 0.958 & 3.49 n.s. (1) & \\
\hline \multicolumn{7}{|c|}{ Note(s): ${ }^{*} p>0.05$; each model compared to the proposed model } & \\
\hline
\end{tabular}

organizational culture where mutual understanding, trust and cooperation become key values to improve these business-to-business relationships (Gounaris, 2005; Kumar et al., 2016; Jang and Park, 2019), the proposal of this research is an original contribution, because it introduces the IM culture perspective that has not been analysed so far in franchise system.

Second, another important theoretical contribution concerns how IM values and behaviours influence the franchise relationship and lead to a successful performance. In this sense, to achieve the franchise goals, this research establishes that the development of an IM culture is positively related to the perception of relevant and useful training provided. On the one hand, this research highlights training relevance as a facilitator that turns IM efforts tangible. On the other hand, regarding useful training (tailored to franchisee's specific needs), the study evidences that an IM culture provides added value to franchisees. In addition, training transfer literature (e.g., Sahoo and Mishra, 2019) has indicated the importance of training relevance as an element that influences motivation towards training and its transfer. In this sense, this work provides an explanation on how a better understanding and implementation of relevant training can be built through the IM culture. Furthermore, this work contributes by delving into the study of training (training relevance and training transfer) as critical factor to transmit the values and knowledge necessary for the success of the franchise system, as suggested by Ioanna and Maria (2013) and Zolfagharian and Naderi (2020), thus responding to the need for research required by the literature (Choo and Bowley, 2007).

Third, it has recently been recommended that, when studying training transfer, researchers should further analyse the particular relationships of each context whereby each training takes place (Baldwin et al., 2017). In this way, the present work makes another relevant contribution by deepening the research of how training and its transfer are conducted in the franchise system. Moreover, to the best of the authors' knowledge, this study explores a connection not previously addressed by training transfer literature. Findings have shown that training transfer is positively related to the perception of a satisfactory franchisor-franchisee relationship. Thus, this significant positive influence is a key determinant to progress in the consolidated and advanced knowledge of franchise success demanded by the literature (Watson and Johnson, 2010; Kalargyrou et al., 2018). In addition, the study also concludes that the influence of training on customer performance is explained indirectly through the relationship satisfaction. In this sense, this study provides further theoretical evidence of the importance of consolidating a good relationship between the parties as a way to improve success and performance, as stated in previous research (Evanschitzky et al., 2011; Nyadzayo et al., 2011). 
First of all, the franchise system needs to be concerned about the relationship quality between parties. Training and support provided by franchisor will create a positive work environment and a valuable learning experience that improve franchisees' feeling of pride at belonging to the franchise system. Thus, these practical aspects must be duly addressed to achieve a higher level of satisfaction in the franchisor-franchisee relationship, as indicated by early studies (Gassenheimer et al., 1996; Choo and Bowley, 2007). This healthy relationship can work as a mitigating factor against temptation for possible franchisee's opportunistic behaviours. Thus, from a practical perspective, this research recommends managers to nurture and support the relationship from an operational, communicative and financial point of view, as Jang and Park (2019) recently pointed out. Due to the results, all these issues will help to develop a satisfactory, valuable and long-term relationship to both parties.

Second, the franchisors must influence the creation and maintenance of a social network by which franchisees and franchisors can work together, synergistically, towards the achievement of common objectives, in line with Zolfagharian and Naderi (2020). In this way, this study proposes that franchisors should foster social ties with franchisees through informal meetings, holding corporate events and so on, which increase mutual understanding and trust (Gounaris, 2005). Evanschitzky et al. (2011) empirically show that improving satisfaction within a franchise greatly enhances the impact of customer satisfaction via their intention to purchase, promoting brand loyalty. Therefore, the present research encourages franchisor to foster a friendly and motivating work environment for their franchisees based on IM culture. Thus, franchisees will be motivated to respond with positive attitudes and behaviours which subsequently improve their brand commitment and customer brand experience (Nyadzayo et al., 2015).

In addition, this work has shown that franchises should invest in building a supportive IM culture, if they are interested in developing a positive and collaborative environment, with continuously harmonious win-win exchanges between franchisor and franchisee. Thus, the IM culture will help motivate franchisees to respond positively to the franchise and to ensure their willingness to continue the relationship for the long term (King et al., 2013).

This research also concludes that the franchisor must provide extensive training to the franchisee to meet technical and operational knowledge needs in order to transform it into a superior added value to the final external customer. From a practical perspective, to achieve this goal, according to Choo and Bowley's (2007) results, the research proposes that franchisors should strive to respond to the franchisees' needs by designing suitable training programmes. In this regard, franchisors should develop training programmes to convey the franchise's core values to their franchisees, focusing on how these values can help them better understand their role and function coherently within the brand; especially considering the importance of goal and value congruence for a sustainable franchise relationship (Weaven et al., 2014b).

Considering IM's practical implications, the present study also proposes that the franchisors should work hard to collect information and disseminate it to the franchisees in order to generate highly relevant and useful perceived training programmes. Based on Baldwin et al. (2009), the present study encourages the franchisee to take an active role in the training process design, in such a way that it is adjusted to their needs and fully responding to the foundations of the IM. In this case, the training design should arise as a cooperative procedure, as part of the co-creation process between franchisor and franchisee. This will increase the value given to the franchisee in this business model, according to a recent conceptual study by Boukis (2019).

Due to the importance of franchisees' perception of training relevance and its subsequent effects on transfer behaviour, franchisors must strive to foster this positive perception. In addition, it must be taken into account, as Barthélemy (2008) points out, that franchisees are 
independent entrepreneurs who cannot be forced to attend all the training sessions that the franchisor considers essential for the updated and effective management of the business model. Therefore, franchisors should assume and promote an IM culture to persuade the franchisees about the importance of continuous learning through training. In line with those suggestions made by Ballantyne (2003), through IM culture, managers will promote mutual exchanges of value in terms of knowledge and practice.

From all the aforementioned contributions, the practical implications of this research are established, summarized in the main idea that, in order to ensure franchise success and customer satisfaction, all franchise parties should play a proactive role in shaping the training programs. This proactive role should be built on a properly developed IM culture to strengthen a successful long-term franchise relationship.

\section{Limitations and future studies}

This work has certain limitations that may become future research lines. Thus, the study was carried out on a specific sample and at a moment in time (cross-sectional study) in which associations between the variables were studied, but no causal relationships could be established. However, future research is intended to advance by conducting a longitudinal study that allows testing the cause-effect relationship between the variables of the model, providing it with a greater degree of robustness.

Furthermore, although the relationship added in alternative Model A slightly improves model fit, its significance may be due to the effect of other variables not included in the original model of this work (e.g., retribution, empowerment, communication) through which IM culture may influence franchisor-franchisee relationship satisfaction. Studying those additional variables, not included in the present model, could be a future line of research.

In addition, it should be noted that these findings have been generated from a franchise system with very specific characteristics. Given its idiosyncrasy, special care should be taken in the possible replication in other contexts. In this sense, it is proposed that future research should analyse this model in born global companies, whose rapid international expansion requires a solid relationship between internationalized partners within the organizational network itself. Finally, and based on the conclusions generated, another interesting line of research is proposed focusing on the analysis of potential differences in organizational performance between franchises that follow an IM culture versus those that do not.

\section{References}

Ahmed, P.K. and Rafiq, M. (2003), "Internal marketing issues and challenges", European Journal of Marketing, Vol. 37 No. 9, pp. 1177-1186, doi: 10.1108/03090560310498813.

Altinay, L., Brookes, M., Yeung, R. and Aktas, G. (2014a), "Franchisees' perceptions of relationship development in franchise partnerships", Journal of Services Marketing, Vol. 28 No. 6, pp. 509-519, doi: 10.1108/JSM-09-2013-0240.

Altinay, L., Brookes, M., Madanoglu, M. and Aktas, G. (2014b), "Franchisees' trust in and satisfaction with franchise partnerships", Journal of Business Research, Vol. 67 No. 5, pp. 722-728, doi: 10. 1016/j.jbusres.2013.11.034.

Anderson, J.C. and Gerbing, D.W. (1988), "Structural equation modeling in practice: a review and recommended two-step approach", Psychological Bulletin, Vol. 103 No. 3, pp. 411-423, doi: 10.1037/0033-2909.103.3.411.

Avlonitis, G.J. and Papastathopoulou, P. (2001), "The development activities of innovative and noninnovative new retail financial products: implications for success", Journal of Marketing Management, Vol. 17 No. 7-8, pp. 705-738, doi: 10.1362/026725701323366791.

Axtell, C.M., Maitlis, S. and Yearta, S.K. (1997), "Predicting immediate and longer-term transfer of training”, Personnel Review, Vol. 26 No. 3, pp. 201-213, doi: 10.1108/00483489710161413. 
Badrinarayanan, V., Suh, T. and Kim, K.-M. (2016), "Brand resonance in franchising relationships: a franchisee-based perspective", Journal of Business Research, Elsevier, Vol. 69 No. 10, pp. 3943-3950, doi: 10.1016/j.jbusres.2016.06.005.

Bagozzi, R.P. and Yi, Y. (1988), "On the evaluation of structural equation models", Journal of the Academy of Marketing Science, Vol. 16 No. 1, pp. 74-94, doi: 10.1007/BF02723327.

Baldwin, T.T. and Ford, J.K. (1988), "Transfer of training: a review and directions for future research", Personnel Psychology, Vol. 41 No. 1, pp. 63-104, doi: 10.1111/j.1744-6570.1988.tb00632.x.

Baldwin, T.T., Ford, J.K. and Blume, B.D. (2009), "Transfer of training 1988-2008: an updated review and agenda for future research", in Hodgkinson, G.P. and Ford, J.K. (Eds), International Review of Industrial and Organizational Psychology, Wiley, Chichester, pp. 41-70, doi: 10.1002/ 9780470745267.ch2.

Baldwin, T.T., Ford, J.K. and Blume, B.D. (2017), "The state of transfer of training research: moving toward more consumer-centric inquiry”, Human Resource Development Quarterly, Vol. 28 No. 1, pp. 17-28, doi: 10.1002/hrdq.21278.

Ballantyne, D. (2003), “A relationship-mediated theory of internal marketing”, European Journal of Marketing, Vol. 37 No. 9, pp. 1242-1260, doi: 10.1108/03090560310486979.

Bansal, H.S., Mendelson, M.B. and Sharma, B. (2001), "The impact of internal marketing activities on external marketing outcomes", Journal of Quality Management, Vol. 6 No. 1, pp. 61-76, doi: 10.1016/s1084-8568(01)00029-3.

Barthélemy, J. (2008), "Opportunism, knowledge, and the performance of franchise chains”, Strategic Management Journal, Vol. 29 No. 13, pp. 1451-1463, doi: 10.1002/smj.

Baruch, Y. and Holtom, B.C. (2008), "Survey response rate levels and trends in organizational research”, Human Relations, Vol. 61 No. 8, pp. 1139-1160, doi: 10.1177/0018726708094863.

Bermúdez-González, G., Sasaki, I. and Tous-Zamora, D. (2016), "Understanding the impact of internal marketing practices on both employees'and managers'organizational commitment in elderly care homes", Journal of Service Theory and Practice, Vol. 26 No. 1, pp. 28-49, doi: 10.1108/JSTP09-2014-0216.

Berry, L.L. (2016), "Revisiting ‘big ideas in services marketing' 30 years later”, Journal of Services Marketing, Vol. 30 No. 1, pp. 3-6, doi: 10.1108/JSM-10-2015-0318.

Berry, L.L. and Parasunaman, A. (1991), Marketing Services: Competing through Quality, The Free Press, New York.

Blau, P.M. (1964), Exchange and Power in Social Life, John Wiley \& Sons, New York.

Blume, B.D., Ford, J.K., Baldwin, T.T. and Huang, J.L. (2010), “Transfer of training: a meta-analytic review", Journal of Management, Vol. 36 No. 4, pp. 1065-1105, doi: 10.1177/0149206309352880.

Bordonaba-Juste, V. and Polo-Redondo, Y. (2008), "The effect of relationship marketing strategy on franchise channels", Journal of Marketing Channels, Vol. 15 No. 1, pp. 71-91, doi: 10.1080/ 10466690802081392.

Boukis, A. (2019), "Internal market orientation as a value creation mechanism", Journal of Services Marketing, Vol. 33 No. 2, pp. 233-244, doi: 10.1108/JSM-10-2017-0336.

Boukis, A., Kostopoulos, G. and Katsaridou, I. (2014), "IMO and different fit types as key enablers of employee brand-supporting behaviour", Journal of Strategic Marketing, Vol. 22 No. 2, pp. 117-134, doi: 10.1080/0965254X.2013.876066.

Boyle, B.A. and Dwyer, F.R. (1995), "Power, bureaucracy, influence, and performance: their relationships in industrial distribution channels", Journal of Business Research, Vol. 32 No. 3, pp. 189-200, doi: 10.1016/0148-2963(94)00045-G.

Brookes, M. and Altinay, L. (2017), "Knowledge transfer and isomorphism in franchise networks", International Journal of Hospitality Management, Vol. 62, pp. 33-42, doi: 10.1016/j.ijhm.2016. 11.012. 
Brookes, M., Altinay, L. and Aktas, G. (2015), "Opportunistic behaviour in hospitality franchise agreements”, International Journal of Hospitality Management, Vol. 46, pp. 120-129, doi: 10.1016/ j.ijhm.2015.02.001.

Brown, J.R. and Dev, C.S. (1997), "The franchisor-franchisee relationship: a key to franchise performance", Cornell Hotel and Restaurant Administration Quarterly, Vol. 38 No. 6, pp. 30-38, doi: 10.1177/001088049703800617.

Burke, L.A. and Hutchins, H.M. (2007), "Training transfer: an integrative literature review", Human Resource Development Review, Vol. 6 No. 3, pp. 263-296, doi: 10.1177/1534484307303035.

Byrne, B.M. (2006), Structural Equation Modeling with EQS: Basic Concepts, Applications, and Programming, 2nd ed., Erlbaum, Mahwah, NJ.

Castrogiovanni, G.J. and Kidwell, R.E. (2010), "Human resource management practices affecting unit managers in franchise networks”, Human Resource Management, Vol. 49 No. 2, pp. 225-239, doi: 10.1002/hrm.20345.

Chien, S.Y. (2014), "Franchisor resources, spousal resources, entrepreneurial orientation, and performance in a couple-owned franchise outlet", Management Decision, Vol. 52 No. 5, pp. 916-933, doi: 10.1108/MD-07-2013-0368.

Chin, W.W. (1998), “Commentary: issues and opinion on structural equation modeling”, MIS Quarterly, Vol. 22 No. 1, pp. vii-xvi, Editorial.

Chiou, J.S., Hsieh, C.H. and Yang, C.H. (2004), "The effect of franchisors' communication, service assistance, and competitive advantage on franchisees' intentions to remain in the franchise system”, Journal of Small Business Management, Vol. 42 No. 1, pp. 19-36, doi: 10.1111/j.1540627x.2004.00095.x.

Choo, S. and Bowley, C. (2007), "Using training and development to affect job satisfaction within franchising”, Journal of Small Business and Enterprise Development, Vol. 14 No. 2, pp. 339-352, doi: 10.1108/14626000710746745.

Cohen, J. (1988), Statistical Power Analysis for the Behavioral Sciences, 2nd ed., Lawrence Erlbaum Associates, Hillsdale, doi: 10.4324/9780203771587.

Croonen, E.P.M. and Brand, M.J. (2015), "Antecedents of franchisee responses to franchisor-initiated strategic change”, International Small Business Journal, Vol. 33 No. 3, pp. 254-276, doi: 10.1177/ 0266242613499805.

Cropanzano, R. and Mitchell, M.S. (2005), "Social exchange theory: an interdisciplinary review", Journal of Management, Vol. 31 No. 6, pp. 874-900, doi: 10.1177/0149206305279602.

Cropanzano, R., Anthony, E.L., Daniels, S.R. and Hall, A.V. (2017), "Social Exchange Theory: a critical review with theoretical remedies", The Academy of Management Annals, Vol. 11 No. 1, pp. 479-516, doi: 10.5465/annals.2015.0099.

Dant, R.P., Weaven, S.K. and Baker, B.L. (2013), "Influence of personality traits on perceived relationship quality within a franchisee-franchisor context", European Journal of Marketing, Vol. 47 Nos 1-2, pp. 279-302, doi: 10.1108/03090561311285556.

Davies, M.A., Lassar, W., Lassar, C., Prince, M. and Winsor, R.D. (2011), "A model of trust and compliance in franchise relationships", Journal of Business Venturing, Vol. 26 No. 3, pp. 321-340, doi: 10.1016/j.jbusvent.2009.09.005.

Dickey, M.H., McKnight, D.H. and George, J.F. (2007), "The role of trust in franchise organizations", International Journal of Organizational Analysis, Vol. 15 No. 3, pp. 251-282, doi: 10.1108/ 19348830710880938.

Domínguez-Falcón, C., Martín-Santana, J.D. and De Saá-Pérez, P. (2017), "Predicting market orientation through internal market orientation as culture and behaviour: an empirical application in Spanish hotels", Service Industries Journal, Vol. 37 Nos 3-4, pp. 229-255, doi: 10.1080/02642069. 2017.1309391. 
Evanschitzky, H., Groening, C., Mittal, V. and Wunderlich, M. (2011), "How employer and employee satisfaction affect customer satisfaction: an application to franchise services", Journal of Service Research, Vol. 14 No. 2, pp. 136-148, doi: 10.1177/1094670510390202.

Facteau, J.D., Dobbins, G.H., Russell, J.E., Ladd, R.T. and Kudisch, J.D. (1995), “The influence of general perceptions of the training environment on pretaining motivation and perceived training transfer”, Journal of Management, Vol. 21 No. 1, pp. 1-25, doi: 10.1016/0149-2063(95)90031-4.

Fernández-Monroy, M. and Melián-Alzola, L. (2005), "An analysis of quality management in franchise systems”, European Journal of Marketing, Vol. 39 Nos 5/6, pp. 585-605, doi: 10.1108/ 03090560510590728.

Fernández-Monroy, M., Martín-Santana, J.D. and Galván-Sánchez, I. (2018), "Building successful franchise partnerships: the importance of communication and trust", Management Decision, Vol. 56 No. 5, pp. 1051-1064, doi: 10.1108/MD-07-2016-0528.

Fornell, C. and Larcker, D.F. (1981), "Evaluating structural equation models with unobservable variables and measurement error", Journal of Marketing Research, Vol. 18 No. 1, pp. 39-50, doi: $10.2307 / 3151312$.

Frazer, L., Merrilees, B. and Wright, O. (2007), "Power and control in the franchise network: an investigation of ex-franchisees and brand piracy", Journal of Marketing Management, Vol. 23 Nos 9-10, pp. 1037-1054, doi: 10.1362/026725707x250458.

Frazer, L., Weaven, S., Giddings, J. and Grace, D. (2012), "What went wrong? Franchisors and franchisees disclose the causes of conflict in franchising", Qualitative Market Research: An International Journal, Vol. 15 No. 1, pp. 87-103, doi: 10.1108/13522751211192017.

Gassenheimer, J.B., Baucus, D.B. and Baucus, M.S. (1996), "Cooperative arrangements among entrepreneurs: an analysis of opportunism and communication in franchise structures", Journal of Business Research, Vol. 36 No. 1, pp. 67-79, doi: 10.1016/0148-2963(95)00164-6.

Gegenfurtner, A., Festner, D., Gallenberger, W., Lehtinen, E. and Gruber, H. (2009), "Predicting autonomous and controlled motivation to transfer training", International Journal of Training and Development, Vol. 13 No. 2, pp. 124-138, doi: 10.1111/j.1468-2419.2009.00322.x.

Ghantous, N. and Das, S.S. (2018), "International franchising and performance: a resource-based perspective", International Journal of Retail and Distribution Management, Vol. 46 No. 8, pp. 744-763, doi: 10.1108/IJRDM-10-2017-0244.

Gillis, W.E., Combs, J.G. and Ketchen, D.J. (2014), "Using resource-based theory to help explain plural form franchising”, Entrepreneurship: Theory and Practice, Vol. 38 No. 3, pp. 449-472, doi: 10.1111/etap.12008.

Gillis, W.E., Combs, J.G. and Yin, X. (2020), "Franchise management capabilities and franchisor performance under alternative franchise ownership strategies", Journal of Business Venturing, Vol. 35 No. 1, p. 105899, doi: 10.1016/j.jbusvent.2018.09.004.

Gounaris, S.P. (2005), "Trust and commitment influences on customer retention: insights from business-to-business services”, Journal of Business Research, Vol. 58 No. 2, pp. 126-140, doi: 10.1016/S0148-2963(03)00122-X.

Gounaris, S.P. (2006), "Internal-market orientation and its measurement", Journal of Business Research, Vol. 59 No. 4, pp. 432-448, doi: 10.1016/j.jbusres.2005.10.003.

Gounaris, S. (2008), "Antecedents of internal marketing practice: some preliminary empirical evidence", International Journal of Service Industry Management, Vol. 19 No. 3, pp. 400-434, doi: 10.1108/09564230810875039.

Gounaris, S.P., Vassilikopoulou, A. and Chatzipanagiotou, K.C. (2010), "Internal-market orientation: a misconceived aspect of marketing theory", European Journal of Marketing, Vol. 44 Nos 11/12, pp. 1667-1699, doi: 10.1108/03090561011079837.

Grace, D. and Weaven, S. (2011), "An empirical analysis of franchisee value-in-use, investment risk and relational satisfaction", Journal of Retailing, Vol. 87 No. 3, pp. 366-380, New York University, doi: 10.1016/j.jretai.2010.06.001. 
Grönroos, C. (2000), Service Management and Marketing, 2nd ed., available at: http://www.amazon. com/Service-Management-Marketing-Customer-Competition/dp/0470028629.

Hair, J.K., Anderson, R.E., Tatham, R.L. and Black, W.C. (1999), Análisis Multivariante, Prentice Hall, Madrid, Vol. 491.

Harmon, T.R. and Griffiths, M.A. (2008), "Franchisee perceived relationship value", Journal of Business and Industrial Marketing, Vol. 23 No. 4, pp. 256-263, doi: 10.1108/08858620810865834.

Hogg, G., Carter, S. and Dunne, A. (1998), "Investing in people: internal marketing and corporate culture", Journal of Marketing Management, Vol. 14 No. 8, pp. 879-895, doi: 10.1362/ 026725798784867563.

Ioanna, S. and Maria, K. (2013), "Information transfer through training in franchising enterprises", Procedia - Social and Behavioral Sciences, Vol. 73, pp. 625-633, doi: 10.1016/j.sbspro.2013.02.099.

Jang, S.C. and Park, K. (2019), "A sustainable franchisor-franchisee relationship model: toward the franchise win-win theory", International Journal of Hospitality Management, Elsevier, Vol. 76 No. Part B, pp. 13-24, doi: 10.1016/j.ijhm.2018.06.004.

Justis, R.T. and Chan, P.S. (1991), "Training for franchise management", Journal of Small Business Management, Vol. 29 No. 3, pp. 87-91.

Kalargyrou, V., Aliouche, E.H. and Schlentrich, U. (2018), "Antecedents and consequences of Franchisee satisfaction in the US restaurant industry", Journal of Human Resources in Hospitality and Tourism, Taylor \& Francis, Vol. 17 No. 1, pp. 60-79, doi: 10.1080/15332845.2017. 1328261.

Kaur, G., Sharma, R.D. and Seli, N. (2009), "Internal market orientation in Indian banking: an empirical analysis", Managing Service Quality, Vol. 19 No. 5, pp. 595-627, doi: 10.1108/ 09604520910984391.

Kidwell, R.E., Nygaard, A. and Silkoset, R. (2007), "Antecedents and effects of free riding in the franchisor-franchisee relationship", Journal of Business Venturing, Vol. 22 No. 4, pp. 522-544, doi: 10.1016/j.jbusvent.2006.06.002.

Kim, M., Pennington-Gray, L. and Kim, J. (2020), "Corporate social responsibility as a determinant of long-term orientation", Service Industries Journal, Taylor \& Francis, Vol. 40 Nos 3-4, pp. 243-267, doi: 10.1080/02642069.2018.1450871.

King, C., Grace, D. and Weaven, S. (2013), "Developing brand champions: a franchisee perspective", Journal of Marketing Management, Vol. 29 Nos 11-12, pp. 1308-1336, doi: 10.1080/0267257X. 2013.796322.

Kumar, G., Banerjee, R.N., Meena, P.L. and Ganguly, K. (2016), “Collaborative culture and relationship strength roles in collaborative relationships: a supply chain perspective", Journal of Business and Industrial Marketing, Vol. 31 No. 5, pp. 587-599, doi: 10.1108/JBIM-12-2014-0254.

Lambe, C.J., Wittmann, C.M. and Spekman, R.E. (2001), "Social exchange theory and research on business-to-business relational exchange", Journal of Business-To-Business Marketing, Vol. 8 No. 3, pp. 1-36, doi: 10.1300/J033v08n03_01.

Larson, P. (2003), "Frontline training for bottom line results", Franchising World, Vol. 35 No. 4, pp. 6-11.

Lee, Y.K., Kim, S.H., Seo, M.K. and Hight, S.K. (2015), "Market orientation and business performance: evidence from franchising industry", International Journal of Hospitality Management, Elsevier, Vol. 44, pp. 28-37, doi: 10.1016/j.ijhm.2014.09.008.

Lings, I.N. (2004), "Internal market orientation - construct and consequences", Journal of Business Research, Vol. 57 No. 4, pp. 405-413, doi: 10.1016/S0148-2963(02)00274-6.

Lings, I. and Greenley, G. (2005), "Measuring internal market orientation”, Journal of Service Research, Vol. 7 No. 3, pp. 290-305. 
Lloret-Segura, S., Ferreres-Traver, A., Hernández-Baeza, A. and Tomás-Marco, I. (2014), "Exploratory item factor analysis: a practical guide revised and updated”, Anales de Psicología, Vol. 30 No. 3, pp. 1151-1169, doi: 10.6018/analesps.30.3.199361.

MacCallum, R.C., Browne, M.W. and Sugawara, H.M. (1996), "Power analysis and determination of sample size for covariance structure modeling”, Psychological Methods, Vol. 1 No. 2, pp. 130-149, doi: 10.1037/1082-989X.1.2.130.

Malhotra, N. and Mukherjee, A. (2004), "The relative influence of organisational commitment and job satisfaction on service quality of customer-contact employees in banking call centres", Journal of Services Marketing, Vol. 18 No. 3, pp. 162-174, doi: 10.1108/08876040410536477.

Merrilees, B. and Frazer, L. (2013), "Internal branding: franchisor leadership as a critical determinant", Journal of Business Research, Vol. 66 No. 2, pp. 158-164, doi: 10.1016/j.jbusres.2012.07.008.

Michael, S.C. (2000), "Investments to create bargaining power: the case of franchising", Strategic Management Journal, Vol. 21 No. 4, pp. 497-514, doi: 10.1002/(sici)1097-0266(200004)21:4<497:: aid-smj87>3.0.co;2-\%23.

Minguela-Rata, B., López-Sánchez, J.I. and Rodríguez-Benavides, M.C. (2010), "Knowledge transfer mechanisms and the performance of franchise systems: an empirical study", African Journal of Business Management, Vol. 4 No. 4, pp. 396-405.

Mosahab, R., Mahamad, O. and Ramayah, T. (2011), "Motivational orientation as an internal marketing tool in service training: a study of service delivery in a hospital", International Journal of Business and Management, Vol. 6 No. 2, pp. 93-100, doi: 10.5539/ijbm.v6n2p93.

Mueller, R.O. (1997), "Structural equation modeling: back to basics", Structural Equation Modeling: A Multidisciplinary Journal, Vol. 4 No. 4, pp. 353-369, doi: 10.1080/10705519709540081.

Mukherjee, A. and Malhotra, N. (2006), "Does role clarity explain employee-perceived service quality?: a study of antecedents and consequences in call centres", International Journal of Service Industry Management, Vol. 17 No. 5, pp. 444-473, doi: 10.1108/09564230610689777.

Nijmeijer, K.J., Fabbricotti, I.N. and Huijsman, R. (2014), "Making franchising work: a framework based on a systematic review", International Journal of Management Reviews, Vol. 16 No. 1, pp. 62-83, doi: 10.1111/ijmr.12009.

Nyadzayo, M.W., Matanda, M.J. and Ewing, M.T. (2011), "Brand relationships and brand equity in franchising", Industrial Marketing Management, Vol. 40 No. 7, pp. 1103-1115, doi: 10.1016/j. indmarman.2011.09.004.

Nyadzayo, M.W., Matanda, M.J. and Ewing, M.T. (2015), "The impact of franchisor support, brand commitment, brand citizenship behavior, and franchisee experience on franchisee-perceived brand image", Journal of Business Research, Vol. 68 No. 9, pp. 1886-1894, doi: 10.1016/j.jbusres. 2014.12.008.

Panigyrakis, G.G. and Theodoridis, P.K. (2009), "Internal marketing impact on business performance in a retail context", International Journal of Retail and Distribution Management, Vol. 37 No. 7, pp. 600-628, doi: 10.1108/09590550910964620.

Paswan, A.K., D'Souza, D. and Rajamma, R.K. (2014), "Value co-creation through knowledge exchange in franchising”, Journal of Services Marketing, Vol. 28 No. 2, pp. 116-125, doi: 10.1108/JSM-092013-0254.

Peltier, J.W., Schibrowsky, J.A. and Nill, A. (2013), "A hierarchical model of the internal relationship marketing approach to nurse satisfaction and loyalty", European Journal of Marketing, Vol. 47 No. 5, pp. 899-916, doi: 10.1108/03090561311306967.

Perrigot, R., Hussain, D. and Windsperger, J. (2015), "An investigation into independent small business owners' perception of franchisee relationships", International Journal of Retail and Distribution Management, Vol. 43 No. 8, pp. 693-711, doi: 10.1108/IJRDM-01-2014-0010.

Perrigot, R., Terry, A. and LerniaDi, C. (2019), "Good faith in franchising: the perceptions of franchisees, franchisors and their lawyers in the French context", International Journal of Retail and Distribution Management, Vol. 47 No. 3, pp. 246-261, doi: 10.1108/IJRDM-02-2018-0043. 
Pitt, L., Napoli, J. and Van der Merwe, R. (2003), "Managing the franchised brand: the franchisees' perspective", Journal of Brand Management, Vol. 10 No. 6, pp. 411-420, doi: 10.1057/palgrave. bm.2540138.

Podsakoff, P.M., MacKenzie, S.B., Lee, J.Y. and Podsakoff, N.P. (2003), "Common method biases in behavioral research: a critical review of the literature and recommended remedies", Journal of Applied Psychology, Vol. 88 No. 5, pp. 879-903, doi: 10.1037/0021-9010.88.5.879.

Preacher, K.J. and Coffman, D.L. (2006), "Computing power and minimum sample size for RMSEA (Computer software)", available at: http://quantpsy.org/.

Rashid, S. and Ghose, K. (2015), "Organisational culture and the creation of brand identity: retail food branding in new markets", Marketing Intelligence and Planning, Vol. 33 No. 1, pp. 2-19, doi: 10.1108/MIP-10-2013-003.

Renta-Davids, A.I., Jiménez-González, J.M., Fandos-Garrido, M. and González-Soto, Á.P. (2014), "Transfer of learning: motivation, training design and learning-conducive work effects", European Journal of Training and Development, Vol. 38 No. 8, pp. 728-744, doi: 10.1108/EJTD03-2014-0026.

Roh, E.Y. and Yoon, J.H. (2009), "Franchisor's ongoing support and franchisee's satisfaction: a case of ice cream franchising in Korea", International Journal of Contemporary Hospitality Management, Vol. 21 No. 1, pp. 85-99, doi: 10.1108/09596110910930205.

Rosado-Serrano, A. and Paul, J. (2018), “A new conceptual model for international franchising”, International Journal of Hospitality Management, Vol. 75, May, pp. 179-188, doi: 10.1016/j.ijhm. 2018.05.024.

Rouiller, J.Z. and Goldstein, I.L. (1993), "The relationship between organizational transfer climate and positive transfer of training", Human Resource Development Quarterly, Vol. 4 No. 4, pp. 377-390, doi: 10.1002/hrdq.3920040408.

Sahoo, M. and Mishra, S. (2019), "Effects of trainee characteristics, training attitudes and training need analysis on motivation to transfer training", Management Research Review, Vol. 42 No. 2, pp. 215-238, doi: 10.1108/MRR-02-2018-0089.

Sanzo, M.J., Santos, M.L., García, N. and Trespalacios, J.A. (2012), "Trust as a moderator of the relationship between organizational learning and marketing capabilities: evidence from Spanish SMEs", International Small Business Journal, Vol. 30 No. 6, pp. 700-726, doi: 10.1177/ 0266242611418907.

Satorra, A. and Bentler, P. (2001), "A scaled difference chi-square test statistic for moment structure analysis", Psychometrika, Vol. 66 No. 4, pp. 507-514, doi: 10.1007/BF02296192.

Schumaker, R.E. and Lomax, R.G. (2010), A Beginner's Guide to Structural Equation Modeling, 3rd ed., Routledge, New York.

Spanish Franchise Association (2020), Franchising in Spain, Report 2020.

Tannenbaum, S.I. (1997), "Enhancing continuous learning: diagnostic findings from multiple companies", Human Resource Management, Vol. 36 No. 4, pp. 437-452, doi: 10.1002/(SICI) 1099-050X(199724)36:4<437::AID-HRM7>3.0.CO;2-W.

Tortosa-Edo, V., Llorens-Monzonís, J., Moliner-Tena, M.A. and Sánchez-García, J. (2015), “The influence of internal market orientation on external outcomes: the mediating role of employees' attitudes", Journal of Service Theory and Practice, Vol. 25 No. 4, pp. 486-523, doi: 10.1108/JSTP11-2013-0259.

Tsai, W.C. and Tai, W.T. (2003), "Perceived importance as a mediator of the relationship between training assignment and training motivation”, Personnel Review, Vol. 32 No. 2, pp. 151-163, doi: $10.1108 / 00483480310460199$.

Tsai, Y. and Tang, T.W. (2008), "How to improve service quality: internal marketing as a determining factor", Total Quality Management and Business Excellence, Vol. 19 No. 11, pp. 1117-1126, doi: $10.1080 / 14783360802323479$. 
Turab, G.M. and Casimir, G. (2015), "A model of the antecedents of training transfer”, International Journal of Training Research, Vol. 13 No. 1, pp. 82-95, doi: 10.1080/14480220.2015.1051352.

Vance, C.M., Chow, I.H.S., Paik, Y. and Shin, K.Y. (2013), "Analysis of Korean expatriate congruence with Chinese labor perceptions on training method importance: implications for global talent management”, International Journal of Human Resource Management, Vol. 24 No. 5, pp. 985-1005, doi: 10.1080/09585192.2012.743475.

Varey, R.J. (1995), "Internal marketing: a review and some interdisciplinary research challenges", International Journal of Service Industry Management, Vol. 6 No. 1, pp. 40-63, doi: 10.1108/ 09564239510078849.

Varotto, L.F. and Parente, J.G. (2016), "Franchisor-franchisee relationship quality: time of relationship and performance", Revista de Administracao de Empresas, Vol. 56 No. 6, pp. 600-610, doi: 10.1590/s0034-759020160603.

Watson, A. and Johnson, R. (2010), "Managing the franchisor-franchisee relationship: a relationship marketing perspective", Journal of Marketing Channels, Vol. 17 No. 1, pp. 51-68, doi: 10.1080/ 10466690903436305.

Weaven, S.K., Grace, D.A., Frazer, L. and Giddings, J. (2014a), "Processual antecedents of perceived channel conflict in franchising", Journal of Business Economics and Management, Vol. 15 No. 2, pp. 316-334, doi: 10.3846/16111699.2012.711362.

Weaven, S.K., Grace, D.A., Dant, R. and Brown, J.R. (2014b), "Value creation through knowledge management in franchising: a multi-level conceptual framework", Journal of Services Marketing, Vol. 28 No. 2, pp. 97-104, doi: 10.1108/JSM-09-2013-0251.

Wickert, A. and Herschel, R. (2001), "Knowledge-management issues for smaller businesses", Journal of Knowledge Management, Vol. 5 No. 4, pp. 329-337, doi: 10.1108/13673270110411751.

Xiao, J. (1996), "The relationship between organizational factors and the transfer of training in the electronics industry in Shenzhen, China”, Human Resource Development Quarterly, Vol. 7 No. 1, pp. 55-73, doi: 10.1002/hrdq.3920070107.

Yang, J.-T. (2015), "Effect of internal marketing on knowledge sharing and organisational effectiveness in the hotel industry", Total Quality Management and Business Excellence, Vol. 26 Nos 1/2, pp. 76-92, doi: 10.1080/14783363.2012.661131.

Yelon, S.L., Ford, J.K. and Golden, S. (2013), "Transfer over time: stories about transfer years after training", Performance Improvement Quarterly, Vol. 25 No. 4, pp. 43-66, doi: 10.1002/piq.21131.

Yu, H.-K., Kim, H. and Kim, Y. (2012), "Factors affecting performance of casual wear franchise stores", Korean Journal of Human Ecology, Vol. 21 No. 2, pp. 269-284, doi: 10.5934/kjhe.2012.21.2.269.

Yu, Q., Barnes, B.R. and Ye, Y. (2020), “Investigating internal market orientation: is context relevant?", Qualitative Market Research: An International Journal, Vol. 23 No. 3, pp. 523-539, doi: 10.1108/ QMR-12-2017-0159.

Zolfagharian, M. and Naderi, I. (2020), "Human resource management challenges facing franchise businesses", Personnel Review, Vol. 49 No. 1, pp. 104-124, doi: 10.1108/PR-04-2018-0139.

\section{Corresponding author}

Margarita Fernández-Monroy can be contacted at: margarita.fernandez@ulpgc.es 


\section{Appendix}

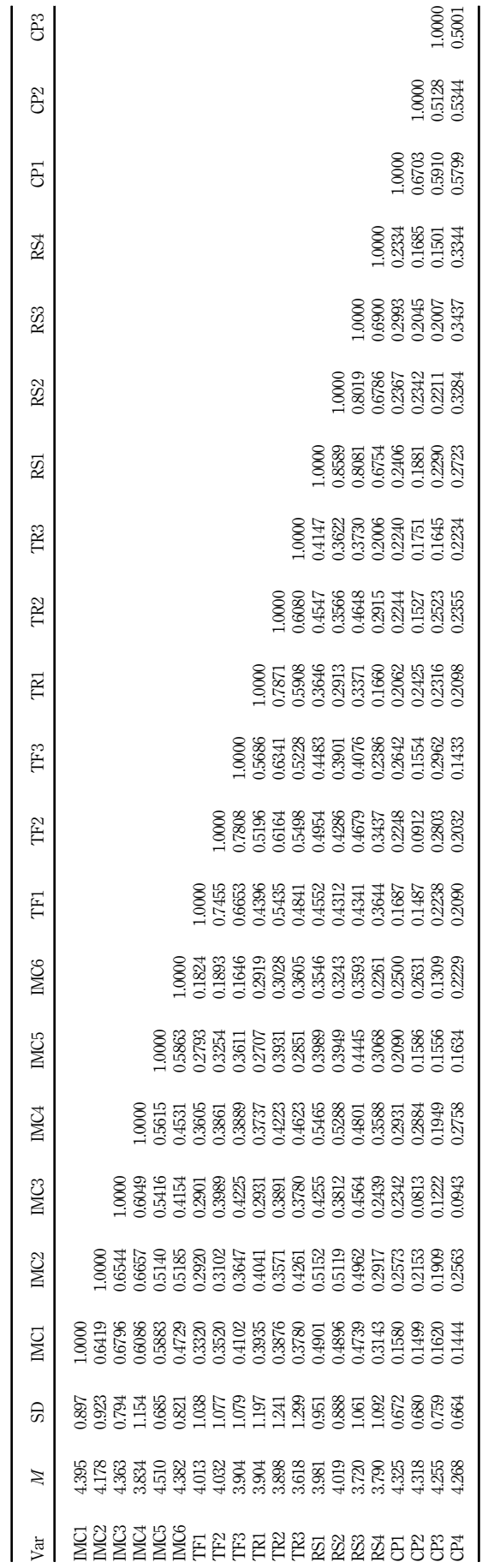

Training as an internal marketing tool 